\title{
Identifikasi kesesuaian tata letak tanaman berdasarkan konsep Tri Mandala (studi kasus Pura Puseh lan Desa, Desa Pakraman Batuan dan Desa Pakraman Kebon Singapadu)
}

\author{
I Gusti Ayu Agung Andari Widyastuti ${ }^{1}$, Anak Agung Gede Sugianthara ${ }^{1 *}$, \\ Cokorda Gede Alit Semarajaya ${ }^{1}$ \\ 1. Program Studi Arsitektur Pertamanan, Fakultas Pertanian, Universitas Udayana, \\ Jl. PB. Sudirman, Denpasar, Indonesia \\ *E-mail: sugianthara@unud.ac.id
}

\begin{abstract}
Suitability Identification of Plant Placement based on Tri Mandala Concept (Case Study Pura Puseh Ian Desa, Desa Pakraman Batuan and Desa Pakraman Kebon Singapadu). Temple is a shrine of Hindu religion and is one of the places for the application of traditional Balinese garden. Temples's garden should use upakara plant that not only serves as a landscape element but also can be used as a means offering (upakara). The concept of plant placement in the temple's garden should also characterize the local philosophy, including Tri Mandala. The purpose of this study is to identify plants type and conformity of plants placement in Pura Puseh lan Desa, Desa Pakraman Batuan and in Pura Puseh Lan Desa, Desa Pakraman Kebon Singapadu based on Tri Mandala concept. The study uses survey methods with data collection techniques, through field observations, interviews, and library studies. The results showed that the two temples used upakara plants and ornamental plants as soft elements. The concept of plants placement is largely in accordance with the concept of Tri Mandala.
\end{abstract}

Keywords : plants placement, Balinese Traditional Garden, temple's garden, Tri Mandala, plants.

\section{Pendahuluan}

Bali merupakan sebuah pulau yang memiliki bentang alam indah dan memiliki budaya yang beragam. Bali juga dikenal dengan konsep pertamanan Balinya atau biasa disebut dengan Taman Tradisional Bali. Taman di Bali tidak hanya melibatkan segi arsitektural, fungsional, estetika, tetapi juga melibatkan filosofi budaya Bali pada setiap penempatan komponen pertamanannya, sehingga memiliki pola yang sedemikian rupa untuk setiap komponen yang ada (Prajoko, 2012). Keunikan dan kekhasan dari Taman Tradisional Bali sangat berpotensi dikembangkan sebagai suatu keunggulan di bidang desain pertamanan. Pura merupakan tempat suci Agama Hindu dan merupakan salah satu tempat untuk melihat bentuk pengaplikasian dari Taman Tradisional Bali. Tidak sedikit pura yang ada di Bali menjadi kawasan wisata sehingga mendapatkan perhatian khusus dari pemerintah desa, kabupaten maupun provinsi. Setiap elemen penyusun baik hardscape maupun softscape harus mencirikan filosofi lokal dalam melestarikan budayanya. Bentukan gapura atau candi bentar dan bentuk pelinggih merupakan penciri tradisional Bali dari segi hardscape.

Konsep penempatan tanaman pada setiap pura seharusnya mencirikan filosofi lokal, seperti Tri Hita Karana, Tri Angga, Asta Dala atau Tri Mandala (Dwijendra, 2008). Konsep Tri Mandala adalah konsep pembagian ruang yang sangat melekat dalam kebudayaan Hindu di Bali, seperti pembagian areal rumah, pembagian areal kantor, hingga pembagian areal pura. Tri Mandala juga dapat digunakan sebagai konsep penyusunan wilayah maupun konsep peletakan tanaman dan penyusunan taman tradisional Bali. Konsep Tri Mandala dapat ditemui pada Pura Puseh lan Desa, Desa Pakraman Batuan dan Desa Pakraman Kebon Singapadu.

Pura Puseh lan Desa, Desa Pakraman Batuan merupakan salah satu tempat suci untuk kegiatan keagamaan dan sekaligus kegiatan wisata di dalamnya, yaitu sebagai obyek kunjungan wisata baik domestik maupun mancanegara. Pura Puseh lan Desa, Desa Pakraman Batuan ini telah memberikan kesan Taman Tradisional Bali yang sangat jelas di dalamnya. Pura Puseh lan Desa, Desa Pakraman Kebon Singapadu juga merupakan tempat suci yang unsur Taman Tradisional Bali dapat dilihat dari elemen kerasnya, namun di pura ini tidak tersentuh aktivitas pariwisata seperti di Pura Puseh lan Desa, Desa Pakraman Batuan. Penelitian ini dilakukan guna mengetahui jenis tanaman yang ada serta kesesuaian tata letaknya berdasarkan konsep Tri Mandala di Pura Puseh lan Desa, Desa Pakraman Batuan dan Desa Pakraman Kebon Singapadu. Hasil penelitian ini diharapkan dapat memberikan informasi mengenai tanaman yang 
ditanam dan dapat dijadikan pedoman dalam menentukan konsep peletakan tanaman yang tepat dalam peletakan tanaman berdasarkan konsep Taman Tradisional Bali.

\section{Metode Penelitian}

Studi tentang identifikasi kesesuaian tanaman berdasarkan konsep Tri Mandala (studi kasus Pura Puseh lan Desa, Desa Pakraman Batuan dan Desa Pakraman Kebon Singapadu) ini dilakukan di kawasan Pura Puseh, Pura Desa, Desa Pakraman Batuan dan Desa Pakraman Kebon Singapadu. Penelitian ini dilakukan dengan rentang waktu yang diperkirakan yaitu selama enam bulan yaitu dari bulan April sampai dengan September 2018.

Alat yang digunakan untuk pengumpulan data dalam penelitian ini adalah kamera untuk dokumentasi gambar atau foto di lokasi penelitian, alat perekam suara untuk merekam suara saat wawancara narasumber, lembar wawancara, alat tulis, komputer, untuk mengolah data.

Penelitian ini menggunakan metode survei dengan teknik pengumpulan data, melalui observasi lapangan, wawancara, dan studi pustaka. Observasi lapangan dilakukan untuk mengumpulkan data tentang tanaman dan peletakannya. Wawancara dilakukan terhadap narasumber yang terkait dengan penelitian tentang kesesuaian tanaman berdasarkan konsep Tri Mandala di Pura Puseh Pura Desa, Desa Pakraman Batuan dan Desa Pakraman Kebon Singapadu seperti pengempon pura, Bendesa Adat, Kelian Adat, Pemangku, dan tokoh masyarakat untuk mendapatkan penjelasan yang lebih tepat dan jelas. Studi pustaka dilakukan untuk mencari data yang berhubungan dengan penelitian ini baik diperoleh dari jurnal hasil penelitian, buku, lontar, sumber-sumber tertulis maupun media elektronik (internet).

Penelitian ini menghasilkan persentase kesesuaian tata letak tanaman pada Pura Puseh lan Desa, Desa Pakraman Batuan dan Kebon Singapadu. Acuan penilaian kesesuaian tata letak diambil dari hasil studi pustaka. Studi pustaka yang digunakan adalah penempatan tanaman berdasarkan sifat religious pada Utama Mandala menurut Subamia (2001), Madya Mandala menurut Prastika (2009), dan Nista Mandala menurut Prajoko (2012). Acuan kesesuaian tata letak berdasarkan fungsi lansekap dan morfologi menggunakan pendapat yang dikemukakan oleh Sudarsana, dkk (2015). Acuan kesesuaian tata letak dapat dilihat lebih jelas pada Tabel 1.

Tabel 1. Kriteria Kesesuaian Tata Letak Tanaman berdasarkan Konsep Tri Mandala (Sudarsana, dkk. (2015))

\begin{tabular}{lll}
\hline \multicolumn{1}{c}{ Utama Mandala } & \multicolumn{1}{c}{ Madya Mandala } & \multicolumn{1}{c}{ Nista Mandala } \\
\hline -Tidak berbuah & -Berbuah & -Berbuah \\
-Berbunga & -Berbunga & -Berbunga \\
-Tidak berduri & -Tidak berduri & -Berduri \\
-Tidak bercabang besar & & \\
& & \\
-Nilai estetika & -Nilai estetika & -Nilai estetika \\
-Kontrol pandangan & -Kontrol pandangan & -Kontrol Pandangan \\
-Pengendali iklim mikro & -Pengendali iklim mikro & -Pengendali iklim mikro \\
& -Pembatas fisik & -Pembatas fisik \\
-Tanaman upakara & -Tanaman usada & -Tanaman estetika \\
-Memiliki aura dingin & -Memiliki aura dingin & \\
-Berbau harum & -Berbau harum & \\
\hline
\end{tabular}

\section{Hasil dan Pembahasan}

\subsection{Gambaran Umum Tempat Penelitian}

Pura Puseh lan Desa, Desa Pakraman Batuan terletak di Dusun Tengah, Desa Batuan, Kecamatan Sukawati, Kabupaten Gianyar, Bali. Pura ini terletak di jalan utama Desa Batuan sehingga mudah diakses dari Denpasar. Pura Puseh lan Desa, Desa Pakraman Batuan ini memiliki beberapa arca yang merupakan peninggalan jaman dahulu. Beberapa bangunan yang terdapat pada pura ini seperti candi bentar, candi kurung, pelinggih dengan ukiran-ukiran terlihat menunjukkan kesan Tradisional Bali dan juga menarik perhatian wisatawan. 
Pura Puseh lan Desa, Desa Pakraman Batuan terbagi menjadi beberapa areal, antara lain Pura Puseh, Pura Desa, Pura Pandean dan areal menyimpan arca yang merupakan areal Utama Mandala, pada areal Madya Mandala terdapat beberapa pelinggih dan tiga buah bale, dan yang terakhir areal luar yang merupakan Nista Mandala terdapat tempat parkir pada barat pura serta terdapat pula tempat parkir dan wantilan di seberang pura bagian selatan.

Pura Puseh lan Desa, Desa Pakraman Kebon Singapadu terletak di Desa Singapadu, Kecamatan Sukawati, Kabupaten Gianyar, Bali. Letak pura ini cukup strategis dan dapat diakses melalui beberapa jalur terutama dari Denpasar. Pura ini biasanya ramai pada saat-saat tertentu jika sedang diadakan upacaraupacara tertentu dan banyak warga datang untuk melakukan kegiatan persembahyangan. Beberapa bangunan yang terdapat pada pura ini seperti candi bentar, candi kurung, pelinggih dengan ukiran-ukiran terlihat menunjukkan kesan Tradisional Bali. Pura Puseh lan Desa, Desa Pakraman Kebon Singapadu terbagi menjadi beberapa areal, antara lain Pura Puseh dan Pura Desa yang merupakan areal Utama Mandala, pada areal Madya Mandala terdapat beberapa pelinggih dan dua buah bale, dan yang terakhir areal luar yang merupakan Nista Mandala terdapat tempat parkir dan wantilan.

Pura Puseh lan Desa Kebon Singapadu mendapatkan renovasi pada tahun 2018 untuk mempercantik penampilannya. Renovasi dilakukan pada pelinggih dan bale-bale yang ada. Pembuatan beberapa tempat penanaman (planter) dilakukan untuk meningkatkan kualitas visual dari pura ini. Pada Pura Puseh lan Desa Kebon Singapadu sudah terdapat beberapa tanaman namun tidak diletakkan pada tempat yang strategis dan kurang tertata dengan baik. Beberapa tanaman tersebut tampak mengurangi fungsi sirkulasi dan aksesibilitas pada pura ini.

Berdasarkan data yang diperoleh dari Climate-Data.org tahun 2018, Kecamatan Sukawati memiliki suhu rata-rata sebesar $26,3^{\circ} \mathrm{C}$ sehingga dapat dikatakan sejuk dan memungkinkan adanya aktifitas yang dilakukan pada siang hari. Curah hujan Kecamatan Sukawati adalah $1.894 \mathrm{~mm}$ dalam satu tahun, dengan adanya drainase yang baik akan mengurangi dampak negatif dari curah hujan di Kecamatan Sukawati.

\subsection{Hasil Identifikasi Tanaman}

\subsubsection{Identifikasi pada Pura Puseh lan Desa, Desa Pakraman Batuan}

Pura Puseh lan Desa, Desa Pakraman Batuan memiliki banyak jenis tanaman dan sudah tertata dengan baik. Tanaman tersebut dirancang untuk meningkatkan daya tarik pariwisata dari Pura Puseh lan Desa, Desa Pakraman Batuan sebagai cagar budaya. Perawatan seperti pemangkasan dan penyiraman dilakukan rutin oleh pihak Desa Pakraman selaku pengelola pura tersebut. Tanaman yang ada di Pura Puseh lan Desa Batuan ditanam tersebar pada tiga areal atau Tri Mandala, yaitu Utama Mandala (UM), Madya Mandala (MM), dan Nista Mandala (NM) (Gambar 1).

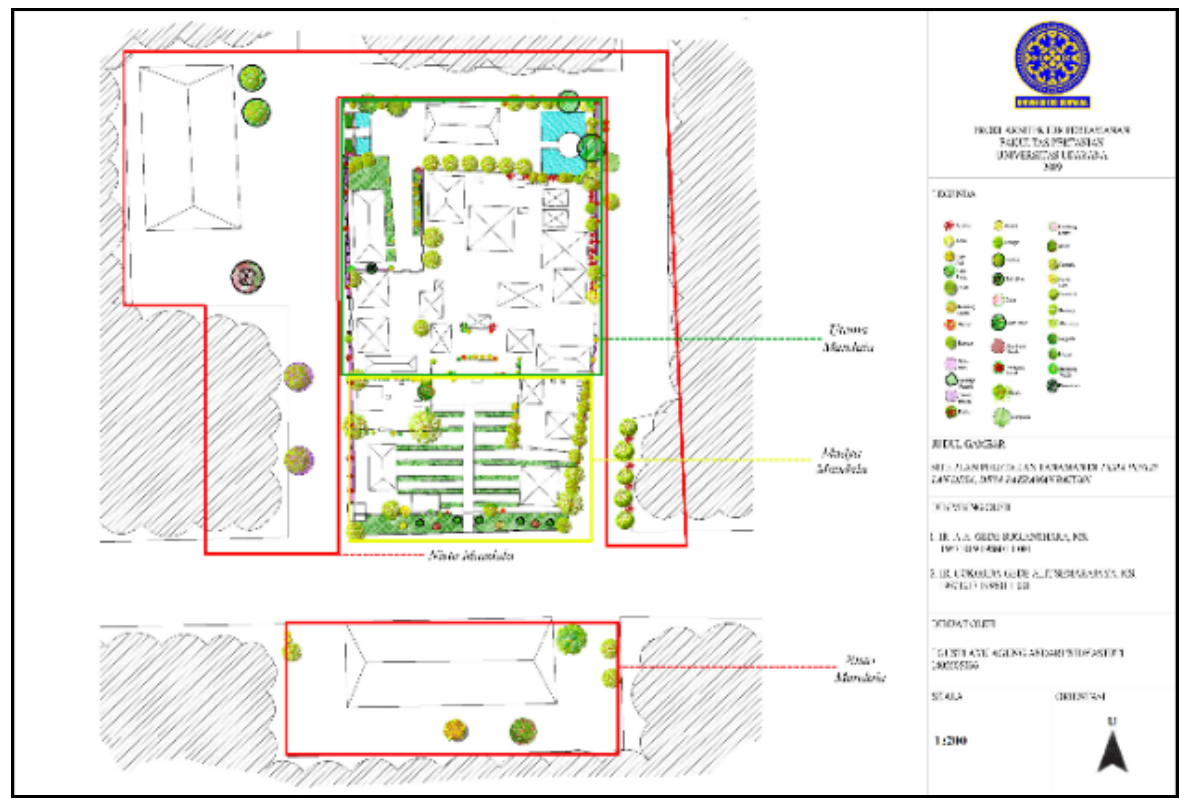

Gambar 1. Site Plan Peletakan Tanaman di Pura Puseh lan Desa, Desa Pakraman Batuan 
Utama Mandala pada pura ini memiliki 26 jenis tanaman dari beragam strata, sembilan jenis tanaman pada Madya Mandala dan 15 jenis tanaman pada Nista Mandala. Rumput yang digunakan pada areal Nista Mandala, Madya Mandala dan Utama Mandala adalah rumput mutiara. Tidak semua tanaman yang ada pada pura ini sudah sesuai dengan konsep Tri Mandala. Penataan tanaman pada pura ini ditujukan untuk mempercantik dan meningkatkan daya tarik wisatanya.

\subsubsection{Identifikasi pada Pura Puseh lan Desa, Desa Pakraman Kebon Singapadu}

Pura Puseh lan Desa, Desa Pakraman Kebon Singapadu memiliki beberapa jenis tanaman dan terlihat kurang tertata. Tanaman yang ada di Pura Puseh lan Desa, Desa Pakraman Kebon Singapadu ditanam tersebar pada tiga areal atau Tri Mandala, yaitu Utama Mandala (UM), Madya Mandala (MM), dan Nista Mandala (NM) dengan jumlah yang berbeda-beda (Gambar 2).

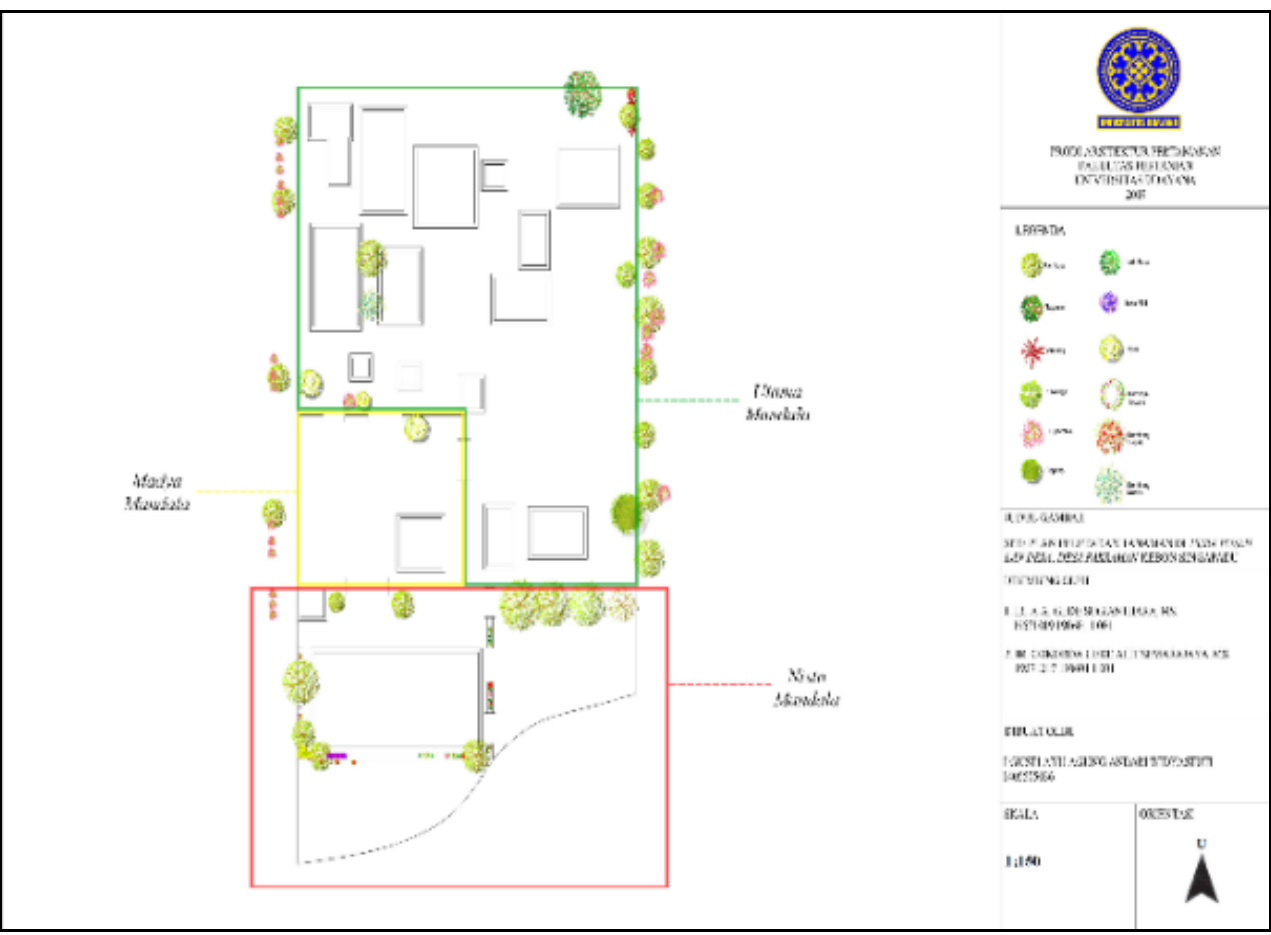

Gambar 2. Site Plan Peletakan Tanaman di Pura Puseh lan Desa, Desa Pakraman Kebon SIngapadu

Utama Mandala pura ini memiliki sembilan jenis tanaman, satu jenis tanaman pada Madya Mandala dan 14. Peletakan tanaman pada Pura Puseh lan Desa, Desa Pakraman Kebon tidak menggunakan konsep, hanya melakukan penataan ulang tanaman yang sudah ada berdasarkan tempat-tempat baru yang tersedia pasca renovasi.

\subsection{Hasil Wawancara}

Wawancara dilakukan dengan Bendesa Adat Batuan dan Wakil Bendesa Adat Kebon Singapadu tentang penanaman pada konsep taman pura. Wawancara ini bertujuan untuk mendapatkan informasi lebih jelas dan lengkap mengenai tanaman dan konsep peletakan tanaman di Pura Puseh lan Desa, Desa Pakraman Batuan dan Pura Puseh lan Desa, Desa Pakraman Kebon Singapadu.

Hasil wawancara menunjukkan bahwa pada kedua Pura Puseh lan Desa tersebut mengalami perubahan keberadaan tanaman. Pihak pengelola Pura Puseh lan Desa, Desa Pakraman Batuan menambahkan beberapa jenis tanaman untuk memperindah pura, sedangkan pada Pura Puseh lan Desa, Desa Pakraman Kebon Singapadu mengalami pengurangan untuk perluasan areal sirkulasi. Pemilihan tanaman yang ada saat ini pada kedua Pura Puseh lan Desa tersebut dikarenakan tanaman tersebut indah, mudah didapat, dan beberapa untuk melengkapi sarana upakara.

Tanaman yang ada saat ini pada kedua pura tersebut juga memiliki fungsi sebagai elemen taman terutama untuk fungsi estetika. Beberapa jenis tanaman yang memiliki fungsi sebagai sarana upakara, umumnya digunakan untuk memperindah pura, namun juga biasa digunakan sebagai sarana upakara jika 
diperlukan. Konsep peletakan tanaman yang ada di kedua pura tersebut menyesuaikan dengan konsep Tri Mandala dengan areal Utama Mandala dan Madya Mandala didominasi oleh tanaman upakara.

Sistem pemeliharaan tanaman di Pura Puseh lan Desa, Desa Pakraman Batuan dilakukan secara rutin dengan melakukan penyiraman setiap hari dan pengecekan tanaman yang kering atau mati setiap minggu. Sistem pemeliharaan di Pura Puseh lan Desa, Desa Pakraman Kebon Singapadu tidak dilakukan secara rutin. Pemeliharaan seharusnya dilakukan secara rutin, namun biasanya pemeliharaan hanya dilakukan ketika diperintahkan. Tanaman yang kering atau mati juga seharusnya diganti, namun karena jarang dilakukan pemeliharaan dan pengecekan, menyebabkan banyaknya tanaman tumbuhnya kurang baik, bahkan ada yang kekeringan dan mati terlihat di areal pura.

\subsection{Kesesuaian Tata Letak Tanaman berdasarkan Konsep Tri Mandala}

Kesesuaian tata letak tanaman dinilai berdasarkan acuan yang tertera pada Tabel 1. Kesesuaian tata letak tanaman pada kedua Pura Puseh lan Desa akan dijelaskan dalam bentuk tabel dengan kolom berupa jenis, jumlah tanaman berdasarkan pembagian ruang Tri Mandala dan kesesuaiannya. Tata letak tanaman pada Pura Puseh lan Desa, Desa Pakraman Batuan dapat dilihat pada Tabel 2.

Tabel 2. Tata Letak Tanaman pada Pura Puseh lan Desa, Desa Pakraman Batuan

\begin{tabular}{|c|c|c|c|c|c|c|}
\hline No. & Nama Tanaman & UM & MM & NM & Jumlah & Kesesuaian \\
\hline 1 & $\begin{array}{l}\text { Alamanda } \\
\text { (Allamanda cathartica) }\end{array}$ & 1 & - & - & 1 & Sesuai \\
\hline 2 & $\begin{array}{l}\text { Ancak } \\
\text { (Hemandia pellata) }\end{array}$ & - & - & 1 & 1 & Sesuai \\
\hline 3 & $\begin{array}{l}\text { Andong } \\
\text { (Cordyline fruticosa) }\end{array}$ & 20 & - & 28 & 48 & Sesuai \\
\hline 4 & $\begin{array}{l}\text { Ararea } \\
\text { (Oxmoxylon lineare) }\end{array}$ & - & - & 265 & 265 & Sesuai \\
\hline 5 & $\begin{array}{l}\text { Belimbing } \\
\text { (Averrhoa carambola) }\end{array}$ & - & - & 1 & 1 & Sesuai \\
\hline 6 & $\begin{array}{l}\text { Belimbing Wuluh } \\
\text { (Averrhoa bilimbi L.) }\end{array}$ & 2 & - & - & 2 & Tidak Sesuai \\
\hline 7 & $\begin{array}{l}\text { Beringin } \\
\text { (Ficus benjamina) }\end{array}$ & - & - & 1 & 1 & Sesuai \\
\hline 8 & $\begin{array}{l}\text { Cabai } \\
\text { (Capsicum annum) }\end{array}$ & 1 & - & - & 1 & Tidak Sesuai \\
\hline 9 & $\begin{array}{l}\text { Cempaka } \\
\text { (Michelia champaca) }\end{array}$ & 1 & - & 5 & 6 & Sesuai \\
\hline 10 & $\begin{array}{l}\text { Dapdap } \\
\text { (Erythrina } \\
\text { microcarpa) }\end{array}$ & 2 & - & - & 2 & Sesuai \\
\hline 11 & $\begin{array}{l}\text { Dewandaru } \\
\text { (Eugenia uniflora) }\end{array}$ & 1 & - & - & 1 & Sesuai \\
\hline 12 & $\begin{array}{l}\text { Intaran } \\
\text { (Azedarachta indica) }\end{array}$ & 1 & - & - & 1 & Sesuai \\
\hline 13 & $\begin{array}{l}\text { Kaca Piring } \\
\text { (Gardenia jasminoides) }\end{array}$ & 14 & 4 & 11 & 29 & Sesuai \\
\hline 14 & $\begin{array}{l}\text { Kamboja } \\
\text { (Plumeria Sp.) }\end{array}$ & 38 & 8 & 3 & 47 & Sesuai \\
\hline 15 & Kamboja Pagoda & - & - & 5 & 5 & Sesuai \\
\hline
\end{tabular}




\begin{tabular}{|c|c|c|c|c|c|c|}
\hline No. & Nama Tanaman & UM & MM & NM & Jumlah & Kesesuaian \\
\hline & (Plumeria "Pagoda") & & & & & \\
\hline \multirow[t]{2}{*}{16} & Katuk & 1 & - & - & 1 & Sesuai \\
\hline & $\begin{array}{l}\text { (Sauropus } \\
\text { androgynus) }\end{array}$ & & & & & \\
\hline \multirow[t]{2}{*}{17} & Kelapa Gading & - & - & 1 & 1 & Sesuai \\
\hline & $\begin{array}{l}\text { (Cocos nucifera } \\
\text { "Gading") }\end{array}$ & & & & & \\
\hline \multirow[t]{2}{*}{18} & Kelapa Hijau & - & - & 1 & 1 & Sesuai \\
\hline & (Cocos nucifera "Gadang") & & & & & \\
\hline \multirow[t]{2}{*}{19} & Kembang Kertas & - & - & 3 & 3 & Sesuai \\
\hline & (Bougainvillea Sp.) & & & & & \\
\hline \multirow[t]{2}{*}{20} & Kembang Merak & - & - & 3 & 3 & Sesuai \\
\hline & (Caesalpinia pulcherrima) & & & & & \\
\hline \multirow[t]{2}{*}{21} & Kembang Sepatu & 14 & 2 & 22 & 38 & Sesuai \\
\hline & (Hibiscus rosasinensis) & & & & & \\
\hline \multirow[t]{2}{*}{22} & Kenanga & 8 & 2 & 14 & 24 & Sesuai \\
\hline & (Canangium odoratum) & & & & & \\
\hline \multirow[t]{2}{*}{23} & Mawar & 4 & - & - & 4 & Sesuai \\
\hline & (Rosa Sp.) & & & & & \\
\hline \multirow[t]{2}{*}{24.} & Mengkudu & 1 & - & 1 & 2 & UM Tidak Sesuai \\
\hline & (Morinda citrifolia) & & & & & \\
\hline 25 & Nagasari & 1 & - & - & 1 & Sesuai \\
\hline \multirow[t]{2}{*}{26} & Nangka & - & - & 2 & 2 & Sesuai \\
\hline & $\begin{array}{l}\text { (Artocarpus } \\
\text { heterophyllus) }\end{array}$ & & & & & \\
\hline 27 & Nusa Indah & 1 & - & - & 1 & Sesuai \\
\hline \multirow[t]{2}{*}{28} & Pacar Cina & 2 & 1 & - & 3 & Sesuai \\
\hline & (Aglaia odorata) & & & & & \\
\hline \multirow[t]{3}{*}{29} & Pandan Wangi & 2 & - & - & 2 & Sesuai \\
\hline & (Pandanus & & & & & \\
\hline & amaryllifolius) & & & & & \\
\hline \multirow[t]{2}{*}{30} & Palasa & 1 & - & - & 1 & Sesuai \\
\hline & (Butea monosperma) & & & & & \\
\hline \multirow[t]{2}{*}{31} & Pranajiwa & 2 & - & - & 2 & Sesuai \\
\hline & (Sterculia foetida L.) & & & & & \\
\hline \multirow[t]{2}{*}{32} & Puring & 1 & 1 & 9 & 11 & Sesuai \\
\hline & (Codiaeum variegatum) & & & & & \\
\hline \multirow[t]{3}{*}{33} & Rumput Jepang & 214.6 & 159.6 & 100 & $474.16 \mathrm{~m}^{2}$ & Sesuai \\
\hline & & $\mathrm{m}^{2}$ & $\mathrm{~m}^{2}$ & $m^{2}$ & & \\
\hline & (Zoysia japonica) & & & & & \\
\hline \multirow[t]{2}{*}{34} & Sambang Darah & - & - & 82 & 82 & Sesuai \\
\hline & (Excoecaria cochinchinensis) & & & & & \\
\hline \multirow[t]{2}{*}{35} & Simbar Menjangan & - & - & 5 & 5 & Sesuai \\
\hline & (Platycerium bifurcatum) & & & & & \\
\hline
\end{tabular}




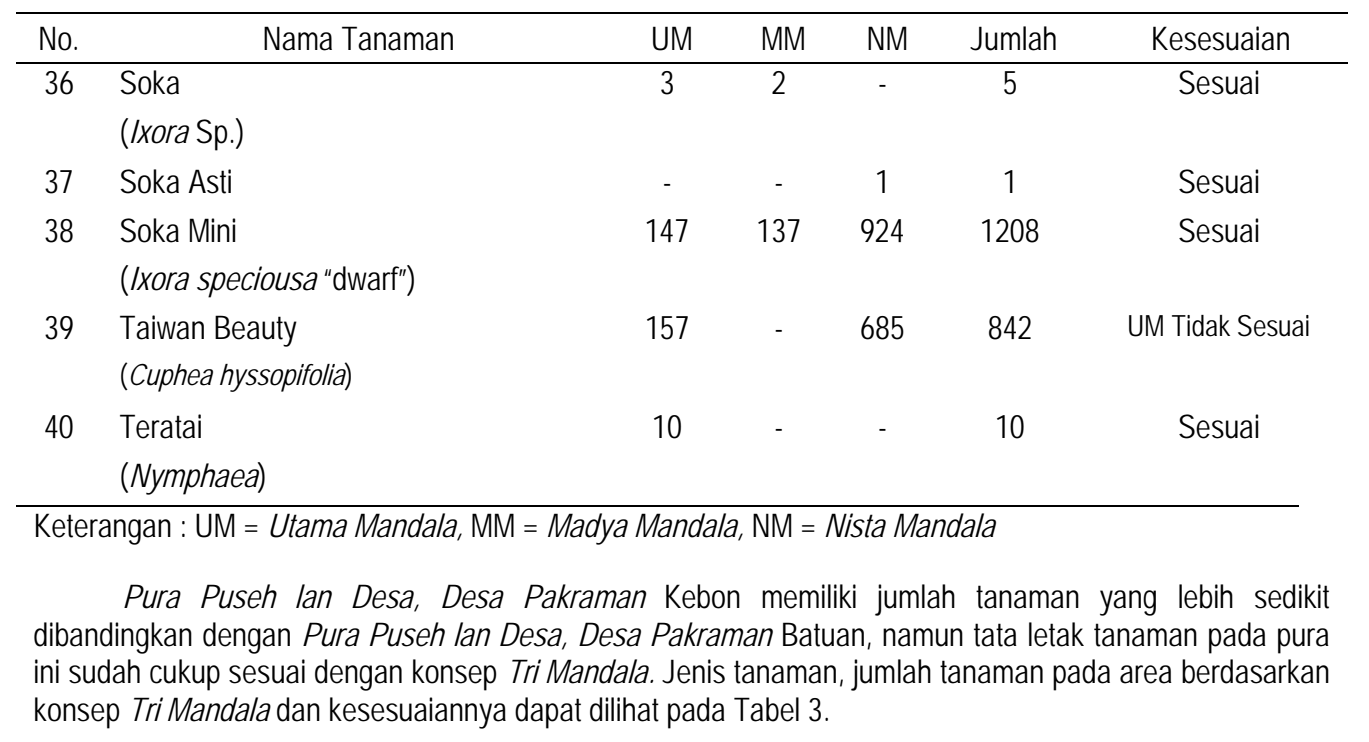

Tabel 3. Kesesuaian Tanaman berdasarkan Tri Mandala pada Pura Puseh lan Desa, Desa Pakraman Kebon

\begin{tabular}{|c|c|c|c|c|c|c|}
\hline No. & Nama Tanaman & UM & MM & NM & Jumlah & Kesesuaian \\
\hline 1 & $\begin{array}{l}\text { Andong } \\
\text { (Cordyline fruticosa) }\end{array}$ & 4 & - & 5 & 9 & Sesuai \\
\hline 2 & $\begin{array}{l}\text { Dapdap } \\
\text { (Erytherina variegata) }\end{array}$ & 1 & - & - & 1 & Sesuai \\
\hline 3 & $\begin{array}{l}\text { Euporbhia } \\
\text { (Euporbhia milii) }\end{array}$ & 1 & - & 17 & 18 & UM Tidak Sesuai \\
\hline 4 & $\begin{array}{l}\text { Kamboja } \\
\text { (Plumeria Sp.) }\end{array}$ & 2 & - & 23 & 23 & Sesuai \\
\hline 5 & $\begin{array}{l}\text { Kamboja Jepang } \\
\text { (Adenium) }\end{array}$ & - & - & 11 & 11 & Sesuai \\
\hline 6 & $\begin{array}{l}\text { Karimbosa Variegata } \\
\text { (Tabernaemontana corymbosa Var.) }\end{array}$ & - & - & 9 & 9 & Sesuai \\
\hline 7 & $\begin{array}{l}\text { Kembang Kertas } \\
\text { (Bougainvillea Sp.) }\end{array}$ & 1 & - & 2 & 3 & UM Tidak Sesuai \\
\hline 8 & $\begin{array}{l}\text { Kembang Sepatu } \\
\text { (Hibiscus rosasinensis) }\end{array}$ & 1 & - & 5 & 6 & Sesuai \\
\hline 9 & $\begin{array}{l}\text { Kenanga } \\
\text { (Canangium odoratum) }\end{array}$ & 1 & - & 1 & 2 & Sesuai \\
\hline 10 & $\begin{array}{l}\text { Nagasari } \\
\text { (Mesua ferrea) }\end{array}$ & 1 & - & - & 1 & Sesuai \\
\hline 11 & $\begin{array}{l}\text { Puring } \\
\text { (Codiaeum variegatum) }\end{array}$ & - & - & 4 & 4 & Sesuai \\
\hline 12 & $\begin{array}{l}\text { Simbar Menjangan } \\
\text { (Platycerium bifurcatum) }\end{array}$ & - & - & 15 & 15 & Sesuai \\
\hline 13 & $\begin{array}{l}\text { Soka } \\
\text { (Ixora Sp.) }\end{array}$ & 2 & 1 & 4 & 7 & Sesuai \\
\hline
\end{tabular}




\begin{tabular}{clccccc}
\hline No. & \multicolumn{1}{c}{ Nama Tanaman } & UM & MM & NM & Jumlah & Kesesuaian \\
\hline 14 & $\begin{array}{l}\text { Soka Mini } \\
\text { (Ixora speciousa "dwarf") }\end{array}$ & - & - & 40 & 40 & Sesuai \\
15 & $\begin{array}{l}\text { Song of India } \\
\text { (Dracaena reflexa) }\end{array}$ & - & - & 1 & 1 & Sesuai \\
16 & $\begin{array}{l}\text { Dieffenbachia zebra } \\
\text { (Dieffenbachia Var.) }\end{array}$ & - & - & 1 & 1 & Sesuai \\
\hline
\end{tabular}

Keterangan : UM = Utama Mandala, MM = Madya Mandala, NM = Nista Mandala

\subsubsection{Tabel Kesesuaian Tata Letak Tanaman berdasarkan Konsep Tri Mandala}

Tabel kesesuaian tata letak merupakan rangkuman dari hasil identifikasi data penelitian. Tabel kesesuaian tata letak tanaman akan menghasilkan persentase kesesuaian tata latak berdasarkan masingmasing pembagian areal pura berdasarkan konsep Tri Mandala. Data kesesuaian tata letak tanaman dapat dilihat lebih jelas pada Tabel 4.

Tabel 4. Kesesuaian Tata Letak berdasarkan Konsep Tri Mandala

\begin{tabular}{|c|c|c|c|c|c|c|}
\hline \multirow{2}{*}{ Keterangan } & \multicolumn{2}{|c|}{ UM } & \multicolumn{2}{|c|}{ MM } & \multicolumn{2}{|c|}{ NM } \\
\hline & $\mathrm{S}$ & TS & $\mathrm{S}$ & TS & $\mathrm{S}$ & TS \\
\hline \multicolumn{7}{|c|}{ 1. Pura Puseh lan Desa, Desa Pakraman Batuan } \\
\hline Jumlah Tanaman & 275 & 162 & 158 & 0 & 2073 & 0 \\
\hline Persentase (\%) & 62.9 & 37.1 & 100 & 0 & 100 & 0 \\
\hline Jumlah Jenis Tanaman & 22 & 5 & 9 & 0 & 24 & 0 \\
\hline Persentase (\%) & 81.5 & 18.5 & 100 & 0 & 100 & 0 \\
\hline \multicolumn{7}{|c|}{ 2. Pura Puseh lan Desa, Desa Pakraman Kebon Singapadu } \\
\hline Jumlah Tanaman & 12 & 2 & 1 & 0 & 138 & 0 \\
\hline Persentase (\%) & 85.7 & 14.3 & 100 & 0 & 100 & 0 \\
\hline Jumlah Jenis Tanaman & 7 & 2 & 1 & 0 & 14 & 0 \\
\hline Persentase (\%) & 77.8 & 22.2 & 100 & 0 & 100 & 0 \\
\hline
\end{tabular}

\subsection{Sintesis Kesesuaian Tata Letak Tanaman berdasarkan Konsep Tri Mandala}

Areal Utama Mandala pada Pura Puseh lan Desa, Desa Pakraman Batuan memiliki beberapa tanaman yang tidak sesuai dengan persyaratan penempatannya seperti belimbing wuluh. Tanaman tersebut tidak cocok karena memiliki buah yang dapat mengotori lingkungan Utama Mandala dan ada yang memiliki percabangan besar sehingga mengancam keselamatan elemen keras dan pengguna tapak. Sebaiknya tanaman ini diganti dengan tanaman berbunga dan tidak berbuah seperti kamboja atau nagasari.

Di areal Utama Mandala pada Pura Puseh lan Desa, Desa Pakraman Kebon Singapadu juga memiliki tanaman yang tidak sesuai. Tanaman tersebut adalah euporbhia, yang bukan merupakan tanaman upakara dan memiliki duri yang cukup banyak sehingga mampu mengancam keselamatan pengguna tapak. Tanaman euporbhia yang ada di areal Utama Mandala lebih baik dihilangkan dan diganti dengan tanaman lain seperti soka atau pucuk.

Tanaman yang ada pada bagian Madya Mandala Pura Puseh lan Desa, Desa Pakraman Batuan sudah sesuai dengan tanaman yang biasa ditanam pada areal Madya Mandala yaitu tanaman yang bunga dan daunnya digunakan dalam upakara seperti kamboja, soka, kembang sepatu, soka mini, kenanga, puring.

Di areal Madya Mandala pada Pura Puseh lan Desa, Desa Pakraman Kebon Singapadu tanaman yang ada juga sudah sesuai dengan yang biasa ditanam yaitu soka. Pada areal Madya Mandala Pura Puseh lan Desa, Desa Pakraman Kebon Singapadu hanya terdapat tanaman soka dikarenakan oleh sempitnya lahan pada areal ini, sehingga tidak memungkinkan untuk menanam tanaman upakara lebih banyak.

Tanaman pada Nista Mandala di Pura Puseh lan Desa, Desa Pakraman Batuan menggunakan tanaman hias daun dan bunga seperti taiwan beauty dan ararea sebagai daya tarik pada Nista Mandala. Nista Mandala pada Pura Puseh lan Desa, Desa Pakraman Kebon Singapadu menggunakan tanaman hias bunga seperti kamboja jepang dan kamboja digunakan sebagai tanaman estetika dan kontrol pandangan. 
Tanaman euphorbia digunakan sebagai tanaman pembatas fisik karena memiliki batang yang berduri dan sekaligus menambah estetika dengan bunganya.

\section{Simpulan dan Saran}

\subsection{Simpulan}

Persentase kesesuaian jumlah dan jenis tanaman pada keseluruhan bagian pura berdasarkan Tri Mandala pada Pura Puseh lan Desa, Desa Pakraman Batuan adalah 87,6\% dan 93,8\% serta persentase ketidaksesuaian jumlah dan jenis tanaman pada keseluruhan bagian pura adalah $12,4 \%$ dan $6,2 \%$. Kesesuaian peletakan tanaman berdasarkan Tri Mandala pada Pura Puseh lan Desa, Desa Pakraman Batuan dan Pura Puseh lan Desa, Desa Pakraman Kebon Singapadu sudah sesuai, namun ada beberapa peletakan yang belum sesuai seperti tanaman belimbing wuluh yang terdapat di areal Utama Mandala. Tanaman hias selain tanaman upakara banyak ditanam di areal Nista Mandala. Pemeliharaan pada Pura Puseh lan Desa, Desa Pakraman Batuan sudah dilakukan secara rutin.

Persentase kesesuaian jumlah dan jenis tanaman pada Pura Puseh lan Desa, Desa Pakraman Kebon adalah $95,2 \%$ dan $92,6 \%$ serta persentase ketidaksesuaian jumlah dan jenis tanaman pada keseluruhan bagian pura adalah 4,8\% dan 7,4\%. Kesesuaian peletakan tanaman berdasarkan Tri Mandala Pura Puseh lan Desa, Desa Pakraman Kebon Singapadu juga sudah ada yang sesuai, namun ada pula yang tidak sesuai yaitu tanaman euphorbia yang ditanam di areal Utama Mandala. Pemelihaan pada Pura Puseh lan Desa, Desa Pakraman Kebon Singapadu tidak rutin sehingga menyebabkan beberapa tanaman kering dan layu.

\subsection{Saran}

Penggunaan tanaman upakara sebagai elemen lunak dan peletakan tanaman dengan konsep Tri Mandala perlu dipertahankan, sehingga pengaplikasian Taman Tradisional Bali betul-betul diterapkan tujuannya untuk memberikan fibrasi atau suasana yang seimbang antar Bhuana Agung dengan Bhuana Alit. Di samping itu tata letak tanaman sesuai konsep Tri Mandala perlu disosialisasikan agar terwujud lingkungan yang indah, lestari, dan lebih harmonis.

\section{Daftar Pustaka}

Dwijendra, Acwin. 2008. Arsitektur Rumah Tradisional Bali: berdasarkan Asta Kosala Kosali. Denpasar. Udayana University Press, Denpasar.

Prajoko, Ahmad. 2012. Pertamanan Tradisional Bali Berlandaskan Unsur Satyam, Siwam, Sundaram, Religi dan Usada [internet]. [diunduh pada 15 Oktober 2016]. Tersedia: http://www.parissweethome.com/ bali/cultural my.php?id=11

Prastika, I N. 2009. Usada Pengobatan Tradisional Bali. E-Jurnal Seni Rupa dan Desain 1(3) : Halaman 2931.

Subamia, I Dewa Putu. 2001. Revitalisasi Taksu Lingkungan Berwawasan Kearifan Lokal Melalui Pembelajaran Taksonomi Tumbuhan Usada dan Upakara (Pendekatan Etnotaksonomi dalam Pendidikan Berwawasan Lingkungan). Jurnal Vegetalika 1(1) :20-31.

Sudarsana, A. A. G. Dalem, S. M. Sarwadana dan A. A. G. Sugianthara. 2015. Tanaman Upakara dan Usada pada Taman Tradisional Bali. Dalam Buku Taman Tradisional Bali. Denpasar. 